\title{
THE RED YARN OF CONTEMPORARY ISLAMIC LAW REFORM: A Critical Study of Abdullahi Ahmed An- Na'im's Thought
}

\author{
Asman \\ Institut Agama Islam Sultan Muhammad Syafiuddin Sambas \\ Fakultas Syariah Hukum Ekonomi Syariah \\ raja.asman86@gmail.com
}

\begin{abstract}
This study analyzes the thoughts of Abdullahi Ahmed an-Na'im in Islamic law reform, Abdullahi Ahmed an-Na'im, a Sudanese intellectual figure. The direction of the objective in this study is directed to reveal Naskh's thinking conceptually, as an object of study that is placed as part of the study of Islamic law studies in discussion. This critical study emphasizes that the need for a review of the naskh principle, for an-Na'im, lies in the necessity to treat the Quran texts in a relevant manner in order to realize adequate reform of Islamic law in a modern context. By understanding the naskh verses in the Koran as a form of delaying their implementation to the right time, he uses a logic or paradigm that is reversed from the conventional naskh principles, namely by re-streamlining the principles of Islamic teachings contained in the verses of the Mecca phase, which in conventional naskh theory it is stated by the Madaniyyah verses that came down later. For him, reversing the naskh process was an evolutionary principle of interpretation. The methods used are descriptive, hermeneutic, and phenomenological methods. In practical terms, his naskh thinking which is aimed at revitalizing the interpretation of Islamic teachings in the context of the modern world can be useful for its application for the good and benefit of the ummah in the reform of Islamic law in Islamic legal reform.
\end{abstract}

Keywords: reformation, Islamic law, critical, Abdullahi Ahmed Na'in

\begin{abstract}
Abstrak: Kajian ini adalah menganalisis pemikiran Abdullahi Ahmed anNa'im dalam reformasi hukum Islam, Abdullahi Ahmed an-Na'im salah seorang tokoh intelektual Sudan. Arah tujuan dalam kajian ini diarahkan untuk menguak pemikiran naskh secara konseptual, sebagai objek kajian yang diletakkan sebagai bagian dari kajian studi hukum Islam dalam pembahruan. Studi kritis ini menegaskan bahwa perlunya peninjauan kembali prinsip naskh, bagi an-Na'im, terletak pada keharusan untuk memperlakukan teks-teks alQuran secara relevan demi mewujudkan pembaruan hukum Islam yang memadai dalam konteks modem. Dengan memahami naskh ayat-ayat dalam al-Quran sebagai suatu bentuk penundaan pelaksanaannya hingga waktu yang
\end{abstract}


tepat, ia menggunakan logika atau paradigma terbalik dari prinsip naskh konvensional, yaitu dengan mengefektifkan kembali prinsip-prinsip ajaran Islam yang terdapat pada ayat-ayat fase Makkah, yang dalam teori naskh konvensional dinyatakan telah oleh ayat-ayat Madaniyyah yang turun belakangan. Baginya, membalikkan proses naskh merupakan prinsip interpretasi yang evolusioner. Metode yang digunakan metode deskriptif, hermeneutika, dan fenomenologi. Secara praktis, bahwa pemikiran naskhnya yang ditujukan untuk merelevansikan penafsiran ajaran Islam dalam konteks dunia modem, dapat berguna penerapannya bagi kebaikan dan kemaslahatan umat dalam pembaharuan hukum Islam dalam reformasi hukum Islam.

Kata kunci: reformasi, hukum Islam, kritis, Abdullahi Ahmed Na'in

\section{INTRODUCTION}

Seen in a very modern development today in Islam, there is a principle of adapting to calls that are not absolute problems of cornering both in matters of thought, rules (law), politics, and so on. ${ }^{1}$ In fact, in the current era of globalization in the thought of handing back to Muslims in determining policies on legal issues against Muslims, among the policies in Islamic law, especially, honesty and trustworthiness. The very first problem that has always been faced by Muslims during the last 2 centuries is to adapt to better adjustments and to change the perspective of Muslim thinking

\footnotetext{
${ }^{1}$ Harun Nasution, Islam Ditinjau Dari Berbagai Aspeknya (Jakarta: Penerbit Universitas Indonesia, 2011). 93.
}

with attractive policies according to religion and in Islamic law. ${ }^{2}$

In this matter, from modern, freedom of opinion, human rights, economic progress and so on, the most important thing is to discuss the desire for law enforcement and a rational way of thinking reasons to describe the cultural problems of Muslims. Islamic law can be understood as the rule of God (Allah SWT) as the creator of life in the world. The rules and regulations consist of all aspects of life, whether they relate to one another, with the natural environment or with God. ${ }^{3}$

2 Asnawi, Studi Hukum Islam: Dari Tekstuali, Rasionalis sampai Rekonsiliatif (Yogyakarta: Teras, 2012). 106.

3 Hug, Kathleen Clack, George, HAM Sebuah Pengantar (Jakarta: Pustaka Sinar Harapan, 1998). 2. 
The development in Islamic law has progressed very rapidly and significantly, for example in human rights. Freedom of opinion is something that must be owned by every individual simply because the individual is a creature created by Allah. The right as an individual is nothing more than an obligation, is general, fair and can be transferred. ${ }^{4}$

There are many figures who support human rights, for example Aung San Suu Kyi, Mahatma Ghandi, Martin Tuther King Jr., Nelson Mandela, as an international humanitarian activist who is an Islamic thinker, Abdullahi Ahmed An-Na'im. His thinking in Islamic legal reform is a social reality in society.

In contrast to secular groups, Abdullahi Ahmed An-Na'im insisted on defending Islamic regulations on the proposed legal reforms. Abdullahi Ahmed AnNa'im's ideas above were of course not born out of nothing. Abdullahi Ahmed an Na'im is a successor of contemporary scholars who were educated as Islamic activists who

\footnotetext{
4 Ibid. 100.
}

had shaped his education in his interventions in social matters. ${ }^{5}$

Contributions to Abdullahi Ahmed an-Na'im's Islamic legal thought cover a very broad range of circumstances, including marriage law, the issue of Islamic apostasy in Africa, the constitution, straf (criminal) law, law between nations, human rights to the state of secularism. Of these many ideologies, the issue of human rights and the state of secularism which is the most prominent has received many votes from other scientists. Then human rights in the attention of Abdullahi Ahmed anNa'im can be attached to very concerning matters such as slavery, gender, and various freedoms. ${ }^{6}$ In this study, the work of Abdullahi Ahmed An-Na'im is used with the title Deconstruction of Sharia, Islam and the Secular State and other supporting works in this paper.

5 Abdullahi Ahmed An Na’im, Sharia Deconstruction. Terjemahan Ahmad Suaedy, Amirudin ar-Rany, (Yogyakarta: LKiS, 2016). 10.

${ }^{6}$ Tholkhatul Khair, Ideologi dan Utopia Pemberlakuan Hukum Islam Studi Pemikiran Abdullabi Abmed an-Naiim Pendekatan Sosiologi Pengetahuan. 127. 
20 | Asman, The Red Yarn of Contemporary Islamic Law..., pp. 17-44

\section{METHOD}

The method used in analyzing the critical study of Abdullahi Ahmed An-Na'im's thoughts in modern Islamic legal reform is as follows:

\section{Descriptive method}

Descriptive means a description of what it is that shows a character's area of an incident. It could also be from a character who concerns his thoughts. ${ }^{7}$

\section{Hermeneutic Methods}

Etymologically, the word hermeneutics originates from the Greek word hermeneuin which means interpreting. Richad E. Palmer defines hermeneutics as the process of forming something or an uncertain situation into understanding. ${ }^{8}$

\section{Phenomenology Method}

The phenomenological method is useful for looking for ideological links with pre-existing social conditions and until the ideology emerges. The method of phenomenology is a method based on the essence of phenomological

\footnotetext{
${ }^{7}$ Khoiriyah, Memahami Metodologi Studi Islam: Suatukonsep tentang selukbeluk Pemahaman Ajaran Islam, studi Islam dan isuisu Kontemporer dalam studiIslam (Yogyakarta: Teras, 2013). 101.

8 Ibid. 103
}

philosophy, which teaches the importance of seeing the visible symptoms of an entity to interpret a realm of thought that is mushrooming in that entity. ${ }^{9}$

And the approach I use is:

\section{Sociological Approach}

This sociological approach examines the phenomenon of religion, namely in terms of studying human behavior in religious life. ${ }^{10}$

\section{Historical Approach}

That is, history has the meaning of the story of a construction which is also called the groups of all past stories. ${ }^{11}$ According to the historical discussion, group it as follows: ${ }^{12}$

1. Discussion on Regions

2. Discussion of the Age

3. Thematic discussion

With the methods and approaches above, the author explains the thoughts of Abdullahi

9 Alex Subur, Filsafat Komunikasi "Tradisi dan Metodologi" (Jakarta: PT Remaja RosdaKarya, 2016). 5-6.

10 Ibid. 87.

11 Jamali Sahrodi, Metodologi Studi Islam Menelusuri jejak. Hoistoris Kajian Islam ala Sarjana Orientalis) (Bandung: Pustaka Setia, 2007). 106.

12 Supiana, Metodologi Studi Islam (Jakarta: Dirjen Pendidikan Islam Depag RI, 2009). 74. 
Ahmed An-Na'im in the reformation of modern Islamic law.

\section{RESULTS AND DISCUSSION}

\section{Biography of Abdullahi}

\section{Ahmed An-Na'im}

Abdullahi Ahmed An-Na'im was born in Sudan on 9 September 1946. Family members Abdullahi Ahmed An-Na'im belong to the middle family members in terms of socio-differentiated population (stratification). Seen in the family really has a very good vision of education. From that, it is no stranger if Abdullahi Ahmed AnNa'im can continue his education up to S3 (doctoral). Abdullahi Ahmed An-Na'im lived his childhood life and adolescence did not depend on his parents with the world's luxury, as happened to children in developed and developing countries.

The era of Abdullahi Ahmed An-Na'im as a teenager and after his return from England was when the State of Sudan became independent. The country of Sudan after its victory faces a very big problem in fighting for a just nationalist leadership. A very devastating incident occurred in the movement of groups that adhered to the concept of Islamic teachings from the Arabs in connection with the name of the State of Sudan and officials in the military who were consistent with the principles of secularism of the Sudanese people.

This makes it difficult for independent Sudan to stabilize the political regime. This is a problem of conflict between Arab Muslims and non-Muslims in the south. About forty percent of Sudanese are Arab residents, however, the Nilotic and Nilo-Cushitic residents, as well as the Dinka, Nuer, and Shilu residents make up half of the local population. The northerners dismissed the southerners from pre-independence political events and from cooperating with the Egyptian and British states. ${ }^{13}$

Abdullahi Ahmed An-Na'im is one of the successors of today's thinkers (contemporary) he is educated and is also a fighter for Islamic human rights who carries out his scholarly duties by participating in matters of social activities in society. Abdullahi Ahmed An-Na'im's experience as a campus activist and advocate who

13 Ibid. 127. 
22 | Asman, The Red Yarn of Contemporary Islamic Law..., pp. 17-44

took part in social problems in the community in his home country of Sudan made his ideology develop. His great belief is his participation in the Persaudaraan Republik, which is chaired by his teacher, Mahmoud Muhammad Taha. ${ }^{14}$ And together with other followers of Mahmoud Muhammad Taha, the group created an organization related to socio-politics called "Tahaism".

Abdullahi Ahmed An-Na'im completed his undergraduate studies at the Khartoum University campus, Sudan State and earned his LL.B title with a very satisfying predicate. After 3 years in 1973 he got the title as well as LL.B, and MA from the University of Cambridge, United Kingdom. In 1976 he received a doctorate (Ph.D) in law and the campus of the Edinburgh State University of Scotland..$^{15}$

Although he comes from a disadvantaged and sad country, Abdullahi Ahmed An-Na'im can

14 Abdullahi Ahmed An Na'im, Sharia Deconstruction Terjemahan Ahmad Suaedy, Amirudin ar-Rany, p. 10

${ }^{15}$ Muh Ilham Usman, Studi Komparasi K.H. Abdurrabman Wabid dan Abdulah Abmad An-Naim tentang Liberasi dan Humanisasi. www.uinalauddin.ac.id/tesis. Diakses 03 November 2020. emerge as a successful worldwide academic, the development of his thinking as a highly educated person stems from the teaching staff in the field of legal science at the Khartoum university campus, Sudan. The teaching history and professional experience are as follows: ${ }^{16}$

\begin{tabular}{|c|c|}
\hline $\begin{array}{l}\text { November } 1976 \\
\text { to June } 1985\end{array}$ & $\begin{array}{l}\text { Expert } \\
\text { Lecturer and } \\
\text { Professor of } \\
\text { Law (Head, } \\
\text { Department } \\
\text { of Public Law } \\
\text { 1979-85) } \\
\text { Khartoum } \\
\text { University, } \\
\text { Sudan }\end{array}$ \\
\hline $\begin{array}{l}\text { August } 1985 \text { to } \\
\text { July } 1987\end{array}$ & $\begin{array}{l}\text { Professor of } \\
\text { Law, at the } \\
\text { Faculty of } \\
\text { Law, } \\
\text { University of } \\
\text { California at } \\
\text { Los Angeles } \\
\text { (UCLA), Los } \\
\text { Angeles, } \\
\text { Canada, } \\
\text { United States }\end{array}$ \\
\hline $\begin{array}{l}\text { August } 1988 \text { to } \\
\text { January } 1991\end{array}$ & $\begin{array}{l}\text { Professor of } \\
\text { Human } \\
\text { Rights, at the } \\
\text { College of } \\
\text { Law, } \\
\text { University of } \\
\text { Saskatchewan, } \\
\text { Canada. }\end{array}$ \\
\hline $\begin{array}{l}\text { August } 1991 \text { to } \\
\text { June } 1992\end{array}$ & $\begin{array}{l}\text { Professor of } \\
\text { law at the } \\
\text { Faculty of } \\
\text { Law, Uppsala } \\
\text { University, } \\
\text { Sweden }\end{array}$ \\
\hline $\begin{array}{l}\text { July } 1992 \text { to June } \\
1993\end{array}$ & $\begin{array}{l}\text { As Visiting } \\
\text { Professor at } \\
\text { the Faculty of } \\
\text { Law, Uppsala }\end{array}$ \\
\hline
\end{tabular}




\begin{tabular}{|c|c|}
\hline & $\begin{array}{l}\text { University, } \\
\text { Sweden }\end{array}$ \\
\hline $\begin{array}{l}\text { July } 1993 \text { to April } \\
1995\end{array}$ & $\begin{array}{l}\text { Executive } \\
\text { Director, } \\
\text { Human } \\
\text { Rights } \\
\text { Institute in } \\
\text { Africa and } \\
\text { Washington }\end{array}$ \\
\hline June 1995 & $\begin{array}{l}\text { As Professor } \\
\text { of Law at } \\
\text { Emory } \\
\text { University, } \\
\text { Atlanta. }\end{array}$ \\
\hline
\end{tabular}

2. Abdullahi Ahmed An-Na'im Thought Method

Islam is a perfect religion brought by Rasulullah SAW. In the years $610 \mathrm{AD}$ to $632 \mathrm{AD}$ Rasulullah SWA spread the contents of the Koran and taught the terms and their proper application so that through the discussion it was further clarified that what is called hadith. From that, these two references, namely the Quran and the hadith, are the basis for the understanding of the term law in Islam and the principles of the objective form of origin that are used by Muslims. ${ }^{17}$

From the explanation above, this step can serve as a basis for the advancement of a better Islamic

17 Abdullahi Ahmed An Na'im, "ISLAM AND SECONDARY COUNTRIES: Negotiating the Future of Sharia". Terjemah, Sri Murniati (Bandung: MIZAN, 2007). 26.
Shari'ah and adjustments to the present and future times. Syari'at is the purpose of life for Muslims. Shari'at can make the laws of Allah SAW and the provisions of the Prophet Muhammad, both in the form of prohibitions and in the form of calls, covering all social aspects and the sustainability of human life. ${ }^{18}$

In the current study of Islamic science, the word syari'ah is commonly seen in Allah SWT's laws such as understanding mubah, sunnah, compulsory, haramd and makruh as well as regarding religious issues, family law, social approaches, economic practice, criminal cases and the field of politics.

The word "sharia" comes from Arabic, Asy-Syarî'ah. Ibn AlManzur in his book Lisân Al'Arab, states that according to the language, the word "syariat" means masyara'ah al-mâ (water source). Ar-Razi explained in his book Mukhtarus Shihah, the word "sharia" means to travel, explain, and show a way. According to $\mathrm{Aj}$ Jurjani, "syari'at" means mazhab 18 M. Daut Ali, Hukum Islam "Pengantar dan tata Hukum Islam di Indonesia" (Jakarta: Raja Grafindo Persada, 2007). 46. 
and tarîqah mustaqîmah or the straight path. ${ }^{19}$

This word is adapted from the origin of the word "syara'a lahum yasyra'u syar'an" which means to make a decision. Described in the Koran, the word syari'ah is once in the word of Allah SW'T QS. alJathiyah [45]: 18, namely:

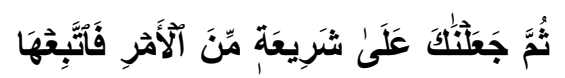

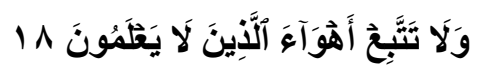

"Then We make you above a sharia (rule) of affairs (religion), so follow that law and do not follow the lusts of those who do not know".

There are two syara'a words with Allah SWT as the subject, the word of Alla SWT QS. ash-Shura [42]: 13, namely:

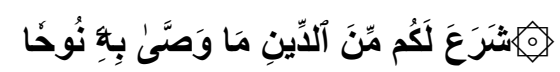

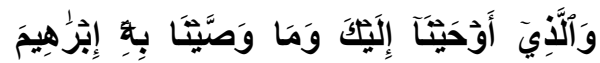

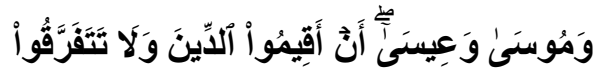

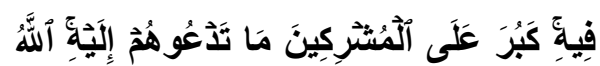

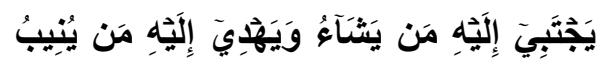
ir

"He has taught you what religion He revealed to Noah and what We

19 Moh. Fauzan Januri, Pengantar Hukum Islam dan Pranata Sosial (Bandung: Pustaka Setia, 2013). 13. have revealed to you and what We have testified to Abraham, Moses and Jesus, namely: Establish religion and do not be divided about it. It is very hard for those religious polytheists that you exclaim to him. Allah draws to that religion the person $\mathrm{He}$ wants and gives instructions to His (religion) those who return (to Him)'.

And as well as relating to people who oppose the religious teachings of Allah SWT, in the word of Allah SWT QS. al-A'raf [7]: 163, namely:

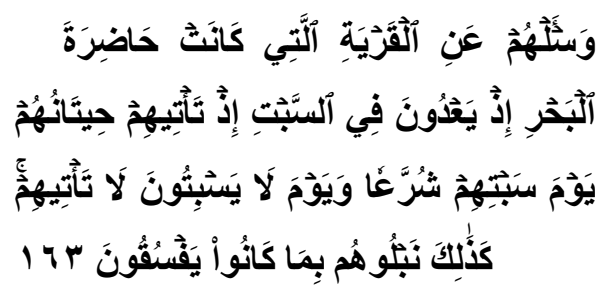

"And ask the Israelites about the land that was near the sea when they broke the rules on Saturday, when they came to them the fish (who were around) they were floating on the surface of the water, and on days that were not. Saturday, the fish did not come to them. Thus We tried them because they were acting wicked ".

Therefore, initially this word was synonymous with religion (din) 
which literally means obedient or obedient. Here, Muslim scholars, especially experts in the field of Islam and preachers, must be able to generalize the view of society, that the teachings of Islam, including the Shari'a, are rahmatan li al-âlamîn, "the theological philosophy is clear", the rules in structuring the relationship between individuals and society are balanced "," prioritizes obligations over rights ", and" does not rigidly separate between criminal and civil sanctions ". ${ }^{20}$

According to Muhammad Asad in his book that Islamic law is Pure which is called shari'ah, it has been translated into Indonesian as follows "The great fuqaha of the past arrived at the discovery of their law based on their study of the qur'an and sunnah, and there is no doubt that examples of the most important exponents of fiqh this study are very profound and conscientious. However, over time these rulings acquired in the popular mind a kind of sacred validity of their own and were later

20 Hartono Mardjono, Menegakkan Syariat Islam dalam Konteks keindonesiaan: proses penerapan Nilai-niai Islam dalam Aspek Hukum, Politik, dan Lembaga Negara. Cetakan I (Bandung: MIZAN, 2007). 31. considered by many Muslims to be an integral part of shari'ah, canon law, itself ". ${ }^{21}$

The source of syari'ah according to Abdullahi Ahmed An-Na'im's thoughts is the Quran, Sunnah, ijma 'and qiyas. In addition, Abdullahi Ahmed An-Na'im also developed the principle of Mahmoud Mohamed Toha's (his teacher) method of thinking, which through his mystical interpretation revives verses erased by the conventional naskh principle for ijtihad and also Abdullahi Ahmed An- $\mathrm{Na}$ 'model of criticism. This is to go beyond the offer of the fundamentalist sharia state and the modern Islamic state of modernity. For Abdullahi Ahmed An Na'im, shari'ah in this case is not all Muslims themselves as only a theoretical view of the basic texts can only be understood in a certain historical context. ${ }^{22}$ Naskh is the foundation of the problem which has great and high complexity in Islamic thought and fiqh.

Abdullahi Ahmed An-Na'im provides an understanding

${ }^{21}$ Muhammad Asad, The Principles of State and Government in Islam (California: Dâr al-Andalus, Gibraltar, 2001). 11 . 22 Ibid. 18. 
foundation for an act and equitable interpretation of the essence and meaning of an Islamic law. $\mathrm{He}$ developed the theory of the naskh of his teacher and integrated it in universal terms of the actual analysis of the conclusions in Islamic law. The first thing is about the justice of Islamic and nonIslamic rights, as well as men and women in determining their own destiny. This is the "human price" that is embedded in the theory of knowledge according to tradition. However, in contrast to secular groups, Abdullahi Ahmed AnNa'im continued to adhere to Islamic law regarding the proposed changes. He believes that in the long run, the radical ideology has little appeal to some Muslims. ${ }^{23}$

For that purpose, Abdullahi Ahmed An-Na'im confirmed the state of shari'ah, because the syari'at is actually a belief in Islam, according to him, is "the product of the process of interpretation of analogical derivation from the text of the Qur'an and Sunna. and other tradition ". ${ }^{24}$ Abdullahi Ahmed an

\footnotetext{
23 Ibid. 9

24 Ahmad Wafiq, Critic of the thoughts of Abdullab Abmed an-Na'im, figure of the Sudan
}

Na'im explained that shari'at is the same as any other system of regulations, following the journey in the advancement of human civilization. $\mathrm{He}$ said "The techniques throught which Shari'a was derivied from the devine sources and the ways in wich in fundamental concepts and principles were formulated are clearly the product of the intellectual, social, and political processes of Muslim history".

After the syari'at was no longer recognized as sacred, for further actions, Abdullahi Ahmed AnNa'im delivered a reformation of the syari'ah. But Abdullahi Ahmed An-Na'im accepted that this reform was carried out within an existing shari'at framework. It is explained that in this framework, his opinion, "ijtihad" is rejected by Islamic law which has been discussed in the Quran with certainty. Other things that must be renewed are Islamic regulations such as the elected nominees such as hudud and qisas law, the status of women and nonIslam, faraidh law and other laws.

\footnotetext{
Lieberal (Pekanbaru: PNKPRESS, 2017).
} 26. 
Abdullahi Ahmed An-Na'im in expressing his opinion tends to express the idea of choice in shari'ah reforms to link conflicts such as syari'ah with the rules of life. The ideas or ideas of Abdullahi Ahmed An-Na'im regarding his way of thinking are as follows:

Sharia as a Historical Product

In the opinion of Abdullahi Ahmed an Na'im, shari'ah is not scientific in character, a meaning that denotes all that is concerned and the detailed regulations were directly revealed by Allah to the Prophet Muhammad. Shari'ah is a historical journey, which produces renewal of the naskh al-Quran and as-Sunnah in line with historical events in the 7 th to 9 th centuries.

From this historical journey, the experts in Islamic law who have been achieved mention the Koran and other scientific references in science to expand the Islamic legal system which has broad insights as a guideline for running for Muslims at that time. As a result of historical travel, the series of Islamic law can be renewed when it feels no longer possible for the continuity of life today.
That is the reason Abdullahi Ahmed an-Naim uses the term formulation of history, to establish a valid statement that is used as a renewal of certain Islamic legal methods so that there will always be reforms in accordance with the times, that is what Abdullahi Ahmed an-Na'im hopes in developing Islamic law.

The opinion of Abdullahi Ahmed an-Na'im about Shari'ah, jurisprudence and regulations in Islam is very difficult to distinguish between the laws, because there are similarities between these laws, for example both are the result of historical studies of the origin of Islamic thought, Quran and asSunnah. In addition, because it refers to terms that are not universally used by most scholars today. ${ }^{25}$

History of Sharia Development in Medina

The current view of Abdullahi Ahmed An-Na'im syariah is no longer possible for today's needs, so this study must be updated in accordance with the current context of sharia. In fact, it is seen as complete or perfect that it is in

25 Ibid. 8. 
the study of sharia at the position of the Medina era.

At this time shari'ah received a more thorough study in science, and at this time there is an explanation in surah al-Maidah [5]: 3 which says that perfection is in Islamic teachings, as follows:

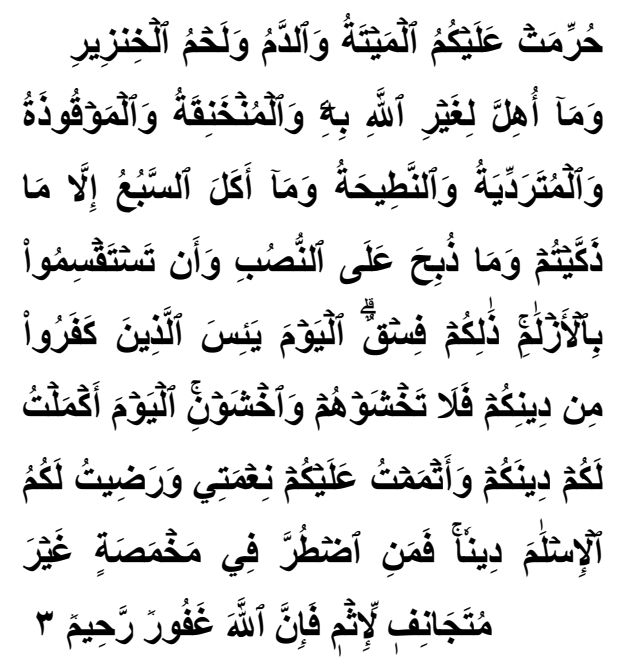

"It is forbidden for you to (eat) carcasses, blood, pork, (animal meat) that were slaughtered in the name other than Allah, those who were strangled, those who were beaten, those who fell, who were gored, and were killed by wild animals, except those you had slaughtered them, and (it is forbidden for you) who were slaughtered for idols. And (it is also forbidden) to draw fate with arrows, (to draw fate with those arrows) is wickedness. On this day the disbelievers have given up (overcoming) your religion, so do not fear them and fear Me. On this day I have perfected your religion for you, and I have filled you with My blessings, and I have accepted Islam as your religion. So whoever is forced due to hunger accidentally commits sins, verily Allah is Forgiving, Most Merciful ".

The explanation of the above verse explains that, all the texts of the Koran, which Muslims believe in a literal and final manner as the words of Allah SWT, were put together very early in Islamic history. The verses of the Quran are considered very clear and need not be argued by all Muslims. ${ }^{26}$ What must be reexamined, in my opinion, is the application of the Qoran as the basis of National law (positive).

According to Abdullahi Ahmed an-Naim, the clear and very careful sharia suspects its closely related nature. This is a clear sign of the closeness of the second dialogue, namely the syari'ah and the real reality it faces. Al-Quran and asSunnah as the main basis of the shari'ah form of response from

\footnotetext{
${ }^{26}$ Ibid. 32.
} 
Islam to the truth is very clear from ancient times, because from that it is also the origin of the present shari'ah as an Islamic response to a clear reality in today's modern times.

Efforts to oblige as a reference to the Quran and as-sunnah as the main references of shari'ah are currently required so that people can always be skilled in conveying the verses of the Koran and assunnah which are appropriate in the lives of Muslims. This is where Abdullahi Ahmed an-Na'im sees the Madaniyah syari'ah which comes from the verse that was revealed in Medina as inappropriate and does not show to answer the problems of Muslims today. because, it can be formulated that the Madaniyah era sharia still distinguishes men and women, Islam and non-Islam. Because people in today's world tend to understand and appreciate the values of equal rights between status and religion.

The context of Medina as understood by Abdullahi Ahmed an-Na'im is a social reality in society experienced by the Muhâjirîn who interacted with the
Ansār, where among the Ansâr there were people who were already believers and non-believers. The pattern of interaction suggested by the Quran at that time was seen as conditional. Abdullahi Ahmed AnNa'im compared the patterns of interaction between contemporary religious communities which are increasingly plural. In addition, people in Muslim countries will also lose the most significant benefits of schularism. ${ }^{27}$

If Muslims stick to the working draft of historical sharia, then they will never truly reach the level of advocating for urgent reforms so that the general rules of Islam can be used today. However, in Islam it is consistent and requires spreading the concept of regulation several possibilities that can anticipate this with modern sharia. Meanwhile, writers on the revival of Islam use the term fundamentalist to refer to contemporary Muslim activists who demand a complete conformity of reality with Islamic teachings, including the total and immediate application of sharia public law.

Historical Development of Sharia in Makkah

27 Ibid. 3. 
30 I Asman, The Red Yarn of Contemporary Islamic Law..., pp. 17-44

After studying the history of sharia in Medina it was said to be inadequate, so Abdullahi Ahmed An-Na'im asked him to leave the sharia. Then Abdullahi Ahmed AnNa'im offered the Makkah sharia which he considered appropriate to the needs of the ummah today. This sharia is what Abdullahi Ahmed An-Na'im referred to later as the final sharia.

\section{Abdullahi Ahmed An-Na'im} views that the message of the Madaniyah verses is a message from Islam which is eternal and fundamental, which emphasizes the internal dignity of all human beings, regardless of gender, religious belief, race, and so on. ${ }^{28}$

For example, Abdullahi Ahmed An-Na'im argued that the Quran during the Madaniyah period always protected all human beings by using the words "O son of Adam", or "O people". In addition, the Makkiyah verse also addresses all human beings with words of great honor and authority regardless of race, ethnicity, skin color, religion and gender. Some

${ }^{28}$ Ibid. 8. information from the Makiyyah verses is as follows: ${ }^{29}$

Differences in belief and norm guidance do not contain legal guidance and their implications. This, unlike the Madaniyah sharia, which provides a trail of discrimination and intolerance, the Makkiyah sharia is more equal and tolerant.

Affirming the qualities of justice and association based on selfrespect which is fixated on all mankind.

Very concerned about the weak. According to the study, Johan Effendi said that in the Quranic letters delivered in Mecca, or at the beginning of Muhammad SAW's prophecy (610-615 AD), there was a sharp criticism of greed and ignorance of social society. Sharia in Makkiyah with these characteristics is what Abdullahi Ahmed An-Na'im has put forward as an option to replace sharia from existing history.

Abdullahi Ahmed An-Na'im said that: "To achieve that degree of reform, we must be able to set

\footnotetext{
29 Zelfeni Wimra, Pemikiran Abdullabi Abmad An-Na'im tentang teori Naskh, http://ejournal.iainjambi.ac.id (Innovatio, Vol xi, No. 2, Juli-Desember 2012): 226229.
} 
aside clear and definite texts of the Qur'an and Sunna of Medina as having served their transitional purpose and implement those texts of the Meccan stage wich were previously inappropriate for practical application but are now the only way to proceed".

This method is then called sharia change, which is "modern and evolutionary interpretation of the Quran". In brief, the changes to the Shari'a can be explained as follows: ${ }^{30}$

It is an open examination of the contents of the Quran and Sunnah which gave birth to two levels or stages of the Islamic message, namely the early period of Mecca and the next in Medina.

The message from Mecca is timeless, fundamental and global; was ordering Medina the opposite.

The historical Sharia makes the verses of Medina as the basis for the legislation of the Sharia by menaskh (delaying the implementation of) the verses of Mecca that cannot be applied.

The current Medina verses are no longer applicable because they contradict modern values.

${ }^{30}$ Ibid. 73.
The verses that came down in Makkah must be re-functioned as the basis for the new sharia legislation by writing verses from Medina.

On the basis of this new legislation a version of Islamic public law is built in accordance with modern values which are none other than the achievements of Western society today.

The opinion of Abdullahi Ahmed An-Na'im in this way is necessary because the basic commands of Islam are contained in the Makkiyyah verses, not those of the Madaniyyah. As for the practice of enforcing laws and politics as stipulated in the Quran and as-Sunnah during the Medina period, said Abdullahi Ahmed AnNa'im, it does not necessarily reflect the commands of the verses of the Makkiyyah. And to establish his method of sharia change, Abdullahi Ahmed An-Na'im used the ideas of Makkiyya, Madaniyyah and the draft of the naskh.

Abdullahi Ahmed An-Na'im's approach also caused problems. Because the opinion of Abdullahi Ahmed An-Na'im seems to conceptualize the absence of 
stability and stability and there is no continuation of the verses in the Koran. He said "the specific political and legal norms of the Qur'an and Sunna of Medina did not always reflect the exact meaning and implications of the message as revealed in Mecca".

This understanding can refute Abdullahi Ahmed An-Na'im's statement that the previous generation of fuqaha arranged the naskh method by eliminating the existing verses in Makkiyyah so that the verses in Madaniyyah could be applied. The naskh method is the last clue when these verses can no longer be equated with other instructions.

So it is no longer possible to simply text verses in Makkiyyah with Madaniyyah verses. Moreover, the pattern of Abdullahi Ahmed An-Na'im's draft of the naskh, the verses that come down first, the Makkiyyah verses, the texts that come down, are called the Madaniyyah verses. ${ }^{31}$ This is of course very difficult to welcome.

31 Ibid. 226-229.

\section{Abdullahi Ahmed An-Na'im Thought Products}

Judging from the thought products of Abdullahi Ahmed AnNa'im are about family law studies including: ${ }^{32}$

On the problem of polygamy, in Surat An-Nisa 'verse 3 states that requiring justice between wives is a requirement for polygamy. Because in Surah An-Nisa 'verse 129 emphasizes that the required justice cannot be achieved. Then it is further explained that the real purpose of the Quran is to abolish polygamy. So the whole text is considered by modern Islamic intellectuals in order to support the limitation of polygamy, instead it advocates polygamy as an exception.

Muslim men may marry Christian or Jewish women. Likewise, a man who is a Christian and a Jew can marry a Muslim woman.

Men and women of various Islam may marry unbelievers, namely individuals who do not believe in the al-scripture that was

\footnotetext{
32 Muhammad Asyrofi, "Konsep Naskh dalam Ijtihad Menurut Pemikiran Abdullabi Abmed An-Na'im". http://ejournal.iainjambi.ac.id. diakses 03 April 2020.
} 
revealed. The assumption arises that if women are allowed to marry non-Muslims, then these women will be easily influenced to leave Islam, compared to the wife dragging her husband to Islam. This reason is one of the more general social facts, namely the weakness of believing each individual in the integrity of women and their better policies.

Disputes in religion are not an obstacle for the heir of property and heirs, so that a person who is Muslim can receive an inheritance and bequeath it to those who are not Muslim.

Men and women are free to choose in their respective religions and beliefs. The principle is ishâmah, not hindered in determining without any acts or acts of violence and coercion. Claiming and exercising individual and collective rights to selfdetermination must also recognize and guarantee the same rights for others. $^{33}$

The abolition of slavery is an example of the acceptance of international human rights as a limit to domestic jurisdiction. The

33 Ibid. 60. anti-slavery movement is a procedure to recognize the principle that violates universal human rights by the state is the concern of other countries. ${ }^{34}$

In his book Sukron Kamil "Thematic Islamic Political Thought" as a modern Islamic thinker we can compare it with Abdullahi Ahmed An-Na'im's opinion on family law and human rights, in articles 24 and 25 of the Law that all elements of human rights must be subject to sharia. The position of the state of Saudi Arabia in its memorandum on Human Rights in Islam in 1970 which bases its perspective on sharia strengthens this premise because it is considered correct. Because for him the only reference for family law and human rights in Islam is sharia.

There are three points of issue concerning family law and human rights. ${ }^{35}$ As follows:

Prohibition of carrying out marriages between Muslim women and men who are not Muslim and prohibition of carrying out

34 Ibid. 60.

35 Sukron Kamil, Pemikiran Islam Tematik (Jakarta: Kencana Prenada Media Group, 2013). 178. 
marriages between men of Muslim faith and female polities (contrary to Article 16 of the UDHR [the Uneversal Declaration of Human Rights [Universal Delecration on Human Rights [DUHAM] 1945).

Prohibition of an individual Muslim from changing religions (contrary to Article 18 UDHR).

Prohibition of the establishment of trade unions (contrary to Article 8 of the International Covenant on Economic, social and Cultural Rights (Foreign Covenant on Economic, Social and Cultural Rights).

After discussing the two thoughts, the writer concludes that in Abdullahi Ahmed An-Na'im's thoughts it is very contrary to the modern concept which prioritizes Sharia as Islamic Law compared to the concept of Abdullahi Ahmed An-Na'im which prioritizes human rights over sharia and the author tends to conceptualize more. now that prioritizes sharia in determining Islamic law in Indonesia.

Because with the background as described above, the concept of the ummah is important in living together, both people in the first, second and third spheres which have a close relationship with the economic, political and sociocultural aspects of a nation or the international world in the era of globalization. This role of the international world is very strong and interactions have become very intensive. $^{36}$

With regard to the issue of the relationship between Islam and a country, Abdullahi Ahmed AnNa'im strictly prevented the design of apostasy (leaving Islam) and the design of dzimmi, because according to Abdullahi Ahmed AnNa'im religion is a way of faith. Plurality is a necessity and a difference is not necessarily an act of injustice. Apart from that, regarding crime or hudud, it is the principle that a criminal act can draw conclusions on monetary compensation as well as the imposition of penalties against the perpetrators.

On the contrary, it is important to determine the nature of the action in light of the significant differences in the evidentiary rules and procedures that can be applied

36 A. Djazuli, Fiqh Siyâsah: Implementasi Umat dalam Ranbu-Rambu Syari'ab (Jakarta: Kencan Prenada Media Group 2007). 259. 
to each type of action. According to Abdullahi Ahmed An-Na'im, it is very important to apply these differences and their application in daily legal practice at the pretrial, judicial and post-trial stages of these actions. ${ }^{37}$

In condemning the contradictions found in various parts of the country related to their efforts to "Islamize the state", especially in terms of the rights imposed on non-Muslims by the Islamic state they want. Abdullahi Ahmed An-Na'im explained that the various contradictions that exist reflect the fundamental problems faced by Islamic thinkers of the subject matter of customary teachings and thinkers who are only guided by the literal attainment of the whole sharia. ${ }^{38}$ It says that:

Islam and the Secular State: Negotiating the Future of Sharia

Abdullahi Ahmed An-Na'im stated that a secularist state that recognizes freedom of religion is compatible and even urgent for Islam. They criticized the idea of

\footnotetext{
37 Ibid. 221-222.

38 Tholkhatul Khair, "Ideologi dan Utopia Pemberlakuan Hukum Islam Studi Pemikiran Abdullabi Abmed an-Naim Pendekatan Sosiologi Pengetahuan". http://journal.uin-suka.ac.id. (2015): 128.
}

removing religion from the public domain. Finally, what Abdullahi Ahmed An-Na'im fought for was the separation of an organization between Islam and the state, while still strengthening the ties between Islam and politics, through what is known as public reason. This method can enable the delivery of Islamic principles in general policies in a legitimate manner, while still adhering to the way the constitution is enforced, and guarantees equal rights for every citizen regardless of religion, race, ethnicity, gender, and political thought.

Proselytization and Communal Self-Determination in Africa,

Abdullahi Ahmed An-Na'im is a designer, who presents theoretical considerations for the political, regulatory and religious foundations in the phenomenon of conversion in African countries as a tangible manifestation that the closeness between religion and human rights is actually a problem and cannot be avoided in all directions. parts of the world.

African Constitutionalism and the Contingent Role of Islam 
Abdullahi Ahmed An-Na'im explained that the constitutional process of a country has not been answered easily. This is because Abdullahi Ahmed An-Na'im firmly believes that the difficulty in solving the above problems only occurs in the process of habituation and indigenous people in the way of the nation state, which is still fundamentally isolated, along with its journey on the map of large political and social organizations. Abdullahi Ahmed An-Na'im calls on Islamic thinkers to take the constitution into its values and apply it to their society.

\section{Abdullahi Ahmed An- Na'im's View on Thought in Sharia Teachings}

With this the source of the results of Abdullahi Ahmed AnNa'im's conversation with Fathiyah Wardah Alatas at Hotel Kristal, South Jakarta about Sharia in his book Secular State ${ }^{39}$, is as follows: ${ }^{40}$

\footnotetext{
${ }^{39}$ Fathiyah Wardah Alatas, Wawancara antara Abm.ad an-Na'im Tentang Syariah dalam bukunya Secular State. www.vhrmedia.com.

40 Wawancara antara Ahmad anNa'im Tentang Syari'ah dalam bukunya Secular State.
}

What is the best thing of sharia law that makes some people want to implement it?

Sharia is Islamic law for Muslims. So, every Muslim is bound by Shariah law, but can not be imposed by the state. When the state took over the right to apply sharia, which means imposing view of the number of people who run the country. Since it became law, the sharia law could conflict with the desire of the majority of Muslims. Therefore, Sharia must remain living in the community who form a civil society to learn and implement sharia. For example, they could form the Islamic bank. But all this must be outside the framework of the country. It is dangerous to let the state claim to be the authority of Islam. In my opinion, sharia is very important in building societies.

What conditions are needed to implement sharia?

Islamic history proves that Muslims are already implementing sharia. That's not new. During the 1,500 years, Muslims already implement sharia. New thing is now we have a country. Human rights should not be imposed by 
the state if the community does not appreciate and execute a matter of human rights. Human reality is Islam, not Western thought. This means that human rights must be at the root of the state, respect for diversity, receive diversity, accept the relationship, respect gender relations.

If it does not live in the community, then those values can not be in the country. A necessary condition is the state should be consistent with the Constitution, the fundamental rights, equality of men and women, equality between Muslims and non-Muslims. This is called civilization. It will not appear in the state before it is formed in the community. Therefore, I have the concept of the right in the house. That is, if we do not teach our children about the respect of human rights, the values of human rights will not live outdoors. HAM regulate interpersonal relationships in which all these relations should be based on the value of equality and respect for others. When that happens in society, it will be reflected in the life of the state. So, what can be done by the state is like that done by the community.
Do you think the Muslim majority countries should implement sharia law?

Not as a country, but as people. As Muslims we should implement sharia. But there is a difference between running and apply. Running is voluntary, while applying means no imposition as opposed to the spirit of sharia. Because sharia respecting freedom of choice and trust people, not on imposition. The Muslims would not agree if imposing sharia state.

Does Indonesia suitable to apply sharia law?

Of course it can not, because of the diversity of backgrounds. Most of these countries have cultural and economic conditions of a typical, distinctive history. Different each other. This condition is very relevant to the community in the area of human rights apply in accordance with the application of sharia. Through the freedom of choice and not by force.

After observing the results of the interview above, the speaker can conclude that Abdullahi Ahmed An-Na'im's view is that Sharia is Islamic law for Muslims. In upholding justice, human rights 
are in fact Islamic teachings, not Western thought. Different from one another, because sharia respects freedom of choice and people's belief, not on the basis of coercion. Muslims certainly do not agree that the state imposes sharia.

\section{Analysis of Abdullahi Ahmed An-Naim's Thought About Sharia}

Cultural diversity in the State of Sudan has a relationship to the diversity of thought and freedom of thought Abdullahi Ahmed AnNa'im. In addition, the place where Abdullahi Ahmed An-Na'im studied also had an impact on Abdullahi Ahmed An-Na'im for his writing maturity, so that he produced many of his written works and received a number of awards, and filled several presentations in various countries.

Abdullahi Ahmed An-Na'im is a contemporary Islamic philosopher who has provided a new discourse on the relationship between Islam and the state. His ideas arise in a design for liberation and a sense of humanity for all peoples of the developing world. Abdullahi Ahmed An-Na'im took action to make changes to sharia by executing a condemnation of traditional sharia which has a dogmative nature.

Abdullahi Ahmed An-Na'im proposed a formulation of sharia with open law in this divine world. Changes in sharia are based on general characteristics that begin to run from the naskh rules which are more emphatic from the verses of Mecca which are more dogmative and do not discriminate. What Abdullahi Ahmed An-Na'im did in his modern nasakh as an effort to establish a foundation related to Islamic culture on human rights in general.

So that because of that, human rights in general get a valid statement in Islam and break down things that have never existed so that they can be welcomed and applied to become a branch of the process of Islamic understanding. There are many pros and cons to Abdullahi Ahmed An-Na'im's views. However, at least its contribution to the discourse that always appears in the Islamic world is a difference that is reflected in the intellectual dynamics that are 
characteristic of contemporary

Muslim life.

Apart from all that, what Abdullahi Ahmed An-Na'im did, provided very useful assistance, namely to make general Islamic religious understandings an inspiration to respond to the challenges of time that are currently running in the lives of Muslims.

Many claim that Abdullahi Ahmed An-Na'im was influenced by Western thought patterns, especially in the fields of linguistics (grammarology), anthropology and psychology. So that the mechanism is considered inaccurate, because it does not refer totally to similar things. In addition, Abdullahi Ahmed An-Na'im is considered to have not mastered well the material of various disciplines and is related to the method of updating this statement, the naskh formulation that has been in the studies of previous scholars.

\section{Critical Notes on the Ideas of Abdullahi Ahmed An- Na'im}

1. Without prejudice to the appreciation and appreciation that should be given to Islamic thinkers, namely Abdullahi Ahmed AnNa'im for his serious efforts to fight for human rights enforcement and seek support for sharia in that direction, and in offering a model of reform to eliminate or minimize the contradiction between both, and in constructing the new sharia formulations that modern society needs there are some unsolved notes that need to be discussed from this study.

2. From a certain perspective, as stated earlier, Abdullahi Ahmed An-Na'im's reform ideas can provide an ideological and cultural foundation for the imperative to uphold human rights, and can also contribute to building a discourse on people's awareness of the need for sharia reform to respond to contemporary problems, especially in completing the shari'ah conflict with human rights.

3. Critical notes on Abdullahi Ahmed An-Na'im's ideas are as follows:

4. Abdullahi Ahmed AnNa'im's view which states that sharia is not revelation itself, which only distinguishes historical interpretations of nasakh (revelation) in the historical context 
of certain Muslims, contradicts the mainstream that Muslims believe so far. Muslims generally believe that the Shari'a is the word of Allah (khithab syari ', text, nasakh), while the interpretation of passages is called fiqh, which can also be referred to as the historical interpretation. In this perspective, Abdullahi Ahmed An-Na'im's ideas can be seen as not conducive to an effort to maintain and develop closeness and adherence to sharia.

5. Regarding the relationship between sharia and human rights, which Abdullahi Ahmed An-Na'im pointed out, there are a number of sharia regulations that are not conducive to human rights, so before abrogating and reforming sharia, as stated by Abdullahi Ahmed An-Na'im, it is necessary to clarify the concept of human rights first and the concept of man himself. An-Na'im in this case places human rights above everything, including sharia, so that when sharia is considered to be at odds with human rights, it must be corrected and equated with human rights. Abdullahi Ahmed AnNa'im's view like this may be because Abdullahi Ahmed An-
Na'im has already accepted human rights as a form of general rule without the slightest flaw.

6. The method used by Abdullahi Ahmed An-Na'im in building his idea was the "reverse nasakh" method, namely abrogating the verses that were spoken in Medina with the verses that came down in Mecca, not like the mutâqaddîmun ulama who adhere to the opposite pattern, namely abrogate the Makiyah verse by the Madaniyah verse. Regarding the use of this method, let alone the use of nasakh in the meaning of mutâqaddîmun itself, which is understood by the wider community so far, among the ulama is still controversial. As far as the situation is related to the Qur'an, there is a conflict between one verse and another which is still in denial (mukhtâlaf fîh). In contrast to the sunnah, contradictions and nasakh in the sunnah are agreed upon (muttafaq'alaih).

7. The part that also needs to be criticized is the categorization of Makkiyah and Madaniyah. In this matter, there are inconsistencies in the thought of Abdullahi Ahmed 
An-Na'im, as a result of the lack of agreement regarding the categorization. As Abdullahi Ahmed An-Na'im himself admitted, there are differences in that category. As a result, there are Makkiyah verses that came down during the Makkah period whose substance contains the characteristics of messages that are commonly sent down in the middle of the Medina. On the other hand, there are verses that came down in the period of Medina, but contain the same messages as the messages of the verses of the period of Mecca in general.

8. With regard to these notes, it can be said that the epistemological framework of the idea of reform in the Islamic deconstruction of Abdullahi Ahmed An-Na'im can still be questioned for its accuracy and validity, at least because the idea is built on unstable or unstable opinion designs and outlines, both in terms of opinion. nasakh which is still commercial, as well as a description of the verses of Makkiyah and Madaniyah which overlap and also still cause debate.

\section{CONCLUSION}

Based on the explanation above, it can be concluded as follows:

The perspective of Abdullahi Ahmed An-Na'im's thinking uses the naskh method which offers the concept of removing the validity of the madaniyah verses by the makkiyah verses. Abdullahi Ahmed An-Na'im's products of thought cover an even range, from al-Ahwal al-Syakhsiyah, issues of conversion in African countries, the constitution, criminal law, foreign law, human rights, to country of secularism.

Human rights in the view of Abdullahi Ahmed An-Na'im can be directed to the issues put forward are servants (slaves), gender, and freedom of religion. Abdullahi Ahmed An-Na'im's views on Shari'ah, fiqh and Islamic law still seem very difficult to link to one another, because it can be seen that their conditions are equal to one another, which are equal and form the results of historical achievements against those originating from the fundamental nature of Islam, Quran and asSunnah. It is therefore also because 
it refers to non-inverse terms used by jurists in general.

According to Abdullahi Ahmed An-Na'im, the process of shari'ah thought must be treated because the mandate which is fundamental in Islam is contained in the Makkiyyah verse, not the Madaniyyah. As for the application of definite rules and politics in the Quran and as-Sunnah during the turbulent period in Medina, according to Abdullahi Ahmed AnNa'im, it does not necessarily reflect the commands of the verses that were revealed in Mecca. And to establish his method of sharia change, Abdullahi Ahmed AnNa'im used the ideas of Makkiyyah and Madaniyyah and ideas from the naskh.

Seeing the epistemological framework of the idea of reform in the Islamic deconstruction of Abdullahi Ahmed An-Na'im, there are still problems with its accuracy and validity, at least because the idea is built on ideas and draft opinions that are not or are not yet solid, both in terms of their nasakh opinion which is still commercial, as well as the design or a description of the verses that were sent down in Makkah and Madinah which are still in question and are still debatable.

\section{REFERENCES}

Alatas Wardah Fathiyah, Wawancara antara Ahm.ad an-Na'im Tentang Syari'ah dalam bukunya Secular State. www.vhrmedia.com.

Ali Daut. M, Hukum Islam "Pengantar dan tata Hukum Islam di Indonesia". Jakarta: Raja Grafindo Persada, 2007

An Na'im Ahmed Abdullahi, "ISLAM AND SECONDARY COUNTRIES: Negotiating the Future of Sharia". Terjemah, Sri Murniati. Bandung: MIZAN, 2007

An Na'im Ahmed Abdullahi, Sharia Deconstruction. Terjemahan Ahmad Suaedy, Amirudin arRany. Yogyakarta: LKiS, 2016

Asad Muhammad, The Principles of State and Government in Islam. California: Dâr al-Andalus, Gibraltar, 2001

Asnawi, Studi Hukum Islam: Dari Tekstuali, Rasionalis sampai Rekonsiliatif. Yogyakarta: Teras, 2012

Asyrofi Muhammad, "Konsep
Naskh dalam Ijtihad
Menurut remikiran
Abdullahi Ahmed An-
Na'im".
journal.iainjambi.ac.id.
diakses 03 April 2020.


Clack Kathleen George, Hug, HAM Sebuah Pengantar. Jakarta: Pustaka Sinar Harapan, 1998

Djazuli. A, Fiqh Siyâsab: Implementasi Umat dalam Ranbu-Rambu Syariah. Jakarta: Kencan Prenada Media Group 2007

Januri Fauzan. Moh, Pengantar Hukum Islam dan Pranata Sosial. Bandung: Pustaka Setia, 2013.

Kamil Sukron, Pemikiran Islam Tematik. Jakarta: Kencana Prenada Media Group, 2013

Khair Tholkhatul, "Ideologi dan Utopia Pemberlakuan Hukum Islam Studi Pemikiran Abdullahi Ahmed an-Na im Pendekatan Sosiologi Pengetahuan". http://journal.uinsuka.ac.id. 2015

Khoiriyah, Memahami Metodologi Studi Islam: Suatukonsep tentang selukbeluk Pemahaman Ajaran Islam, studi Islam dan isu-isu Kontemporer dalam studiIslam. Yogyakarta: Teras, 2013

Mardjono Hartono, Menegakekan Syariat Islam dalam Konteks keindonesiaan: proses penerapan Nilai-niai Islam dalam Aspek Hukum, Politik, dan Lembaga Negara. Bandung: MIZAN, 2007

Nasution Harun, Islam ditinjau dari berbagai aspeknya. Jakarta:
Penerbit Universitas Indonesia, 2011

Sahrodi Jamali, Metodologi Studi Islam Menelusuri jejak Hoistoris Kajian Islam ala Sarjana Orientalis). Bandung: Pustaka Setia, 2007

Salikin Djumhur Dadang, Reformasi Syariah dan HAM dalam Islam, Bacaan Kritis Terbadap Pemikiran An-Na'im. Yogyakarata: GAMA MEDIA, 2004

Subur Alex, Filsafat Komunikasi "Tradisi dan Metodologi". Jakarta: PT Remaja RosdaKarya, 2016

Supiana, Metodologi Studi Islam. Jakarta: Dirjen Pendidikan Islam Depag RI, 2009

Usman Ilham Muh, Studi Komparasi K.H. Abdurrahman Wahid dan Abdulah Ahmad An-Naim tentang Liberasi dan Humanisasi. www.uinalauddin.ac.id/tesis . Diakses 03 April 2020

Wafiq Ahmad, Critic of the thoughts of Abdullab Abmed an-Na'im, figure of the Sudan Lieberal. Pekanbaru: PNKPRESS, 2017

Wimra Zelfeni, Pemikiran Abdullahi Ahmad AnNa'im tentang teori Naskh, Jurnal Innovatio, Vol xi, No. 2, Juli-Desember 2012 